\title{
Повышение продуктивности клонов европейских сортов винограда на основе разработки элементов сортовой \\ агротехнологии
}

Наталия Александровна Урденко, канд. с.-х. наук, ст. науч. сотр. лаборатории агротехнологий винограда,

agromagarach@mail.ru

Магомедсайгит Расулович Бейбулатов, д-р. с.-х. наук, ст. науч. сотр., заведующий лабораторией агротехнологий винограда, agromagarach@mail.ru

Надежда Александровна Тихомирова, канд. с.-х. наук, ст. науч. сотр. лаборатории агротехнологий винограда, nadegda17@bk.ru

Роман Алексеевич Буйвал, канд. с.-х. наук, науч. сотр. лаборатории агротехнологий винограда, agromagarach@mail.ru Федеральное государственное бюджетное учреждение науки «Всероссийский национальный научно-исследовательский институт виноградарства и виноделия «Магарач» РАН», Россия, Республика Крым, 298600, г. Ялта, ул. Кирова, 31

В связи с появлением новых клонов европейских сортов винограда в Крыму возникает необходимость исследований поведения такого критерия как продуктивность кустов и качества получаемой продукции в конкретном природно-климатическом районе. Недостаточная изученность агробиологических и хозяйственно ценных свойств новых клонов технических сортов, отсутствие сведений по качественным характеристикам сырья в условиях Крыма без установления для них оптимальных параметров сортовой агротехники приводит к снижению эффективности возделывания. Поэтому проведение комплексной оценки новых для Крыма клонов европейских сортов винограда, а также разработка элементов сортовой агротехники с оценкой их перспективности является актуальным направлением исследований, поскольку дает возможность более эффективно и целенаправленно использовать биологические и потенциальные возможности новых клонов винограда. В связи с этим основной целью наших исследований, является установление основных агробиологических, количественных и качественных характеристик винограда изучаемых клонов, а также оценка их перспективности возделывания в зависимости от агротехнических факторов - оптимальная величина нагрузки кустов, длины обрезки плодовых лоз в условиях Южнобережной зоны Крыма. Полученные нами экспериментальные данные показали, что исследуемые клоны: Алеатико 802, Мускат белый VCR-3, Каберне-Совиньон R-5 в сравнении с сортами-эталонами проявляют весьма высокую способность плодоношения зимующих глазков и формирования побегов с высокими значениями коэффициентов плодоносности и плодоношения. Выявленные в результате исследований закономерности позволили установить рациональные способы ведения клонов европейских сортов винограда и нагрузку куста глазками, длину обрезки плодовых лоз и влияние изученных агроприемов на качество винограда. Высокоштамбовый способ ведения с формировкой кустов - «АЗОС-1» при ведении их на одноярусных шпалерах способствовал повышению продуктивности клонов сортов винограда Алеатико 802 и Мускат белый VCR-3, а форма куста односторонний горизонтальный кордон на среднем штамбе способствует большему накоплению сахаров в соке ягод клона сорта винограда Мускат белый VCR-3. Повышение нагрузки кустов от 24 до 36 глазков на куст у клона сорта Каберне-Совиньон приводило к увеличению урожайности с 12,2 до 14,8 т/ га, при незначительном снижении сахаристости сока с 23,1 до 22,3 г/100 $\mathrm{cm}^{3}$.

Ключевые слова: клоны европейских сортов; элементы агротехники сорта; агробиология; урожай; качество; коэффициент адаптации; перспективность.
O R I G I N A L R E S E A R C H

Increasing productivity of clones of European grapevine cultivars through the development of varietal agri-technology elements

Natalia Aleksandrovna Urdenko, Magomedsaigit Rasulovich Beibulatov, Nadezhda Aleksandrovna Tikhomirova, Roman Alekseievich Buival

Federal State Budget Scientific Institution All-Russian National Research Institute of Viticulture and Winemaking Magarach of the RAS, 31 Kirova Str., 298600 Yalta, Republic of Crimea, Russian Federation

Introduction of new clones of European grapevine cultivars in Crimea calls for examination of the bush productivity criterion along with the quality of the final product obtained in a particular natural and climatic region of Crimea. Gaps in the knowledge of agrobiological and economically valuable properties of new clones of wine cultivars, the lack of data on quality characteristics of the raw materials in Crimea without established optimal parameters of varietal agricultural practices reduces cultivation efficiency. The above calls for a comprehensive assessment of the new for Crimea clones of European grapevine cultivars, and for development of varietal agricultural practices accompanied by their viability assessment, which would facilitate a more effective and targeted use of the biological and potential capabilities of new grapevine clones. Therefore, our study aims to establish basic agrobiological, quantitative and qualitative characteristics of the studied grapevine clones, and assess their cultivation prospects depending on such agro-technical factors as the optimal bush load and the fruit cane pruning length in the conditions of the southern coast of Crimea. The obtained experimental data revealed that the studied clones 'Aleatico 802', 'Muscat Belyi VCR3 ' and 'Cabernet Sauvignon R-5' have a rather high fruiting ability of wintering eyes and shoot formation with high fruit-bearing capacity and fertility ratios as compared to standard varieties. The revealed patterns allowed establishing a rational training of clones of the European grapevine cultivars and the eye load per bush, the fruit cane pruning length and the influence of the studied agricultural practices on grape quality. The tall trunk training system - "Azos-1" on one-wired trellis increased productivity of clones of 'Aleatiko 802' and 'Muscat Belyi VCR-3' grapes, while the bush shape unilateral horizontal cordon on medium height trunk increased sugar accumulation in the juice of the fruit of clone of 'Muscat Belyi VCR-3'. Bush load increase from 24 to 36 shoots per bush in the clone of 'Cabernet Sauvignon' grapes increased the yield from $12.2 \mathrm{t} / \mathrm{ha}$ to $14.8 \mathrm{t} / \mathrm{ha}$, with a slight decrease in the sugar content of the juice from $23.1 \mathrm{~g} / 100 \mathrm{~cm}^{3}$ to $22.3 \mathrm{~g} / 100 \mathrm{~cm}^{3}$.

Key words: clones of European cultivars; elements of varietal agricultural practices; agrobiology; harvest; quality; adaptation coefficient; viability.

\section{Как цитировать эту статью:}

Урденко Н.А., Бейбулатов М.Р., Тихомирова Н.А., Буйвал Р.А. Повышение продуктивности клонов европейских сортов винограда на основе разработки элементов сортовой агротехнологии // «Магарач». Виноградарство и виноделие, 2019; 21(3); C.229-234. DOI 10.35547/IM.2019.21.3.008 How to cite this article:

Urdenko N.A., Beibulatov M.R., Tikhomirova N.A., Buival R.A. Increasing productivity of clones of European grapevine cultivars through the development of varietal agri-technology elements. Magarach. Vinogradarstvo i vinodelie = Magarach. Viticulture and Winemaking, 2019: 229-234. DOI 10.35547/IM.2019.21.3.008 (in Russian)

удК 634.85:631.524.84 /.526.32:631.542.32

Поступила 28.02.2019

Принята к публикации 20.08.2019

(C) Авторы, 2019 
Increasing productivity of clones of European grapevine cultivars through the development of ...

$\mathrm{B}$ ведение. ВнеАрение в сортимент винограда высокоадаптивных сортов и кАонов обеспечивают Аинамичное развитие отраски.

В настоящее время возросла потребность в попоцнении сортимента винограАа аАаптивными, ценными по агробио огическим и технологическим свойствам, конкурентоспособными сортами и кмонами, внеАрение в производство которых обеспечит повышение рентабельности виноградовинодемьческой отрасли [12, $16,19,20,23]$. Соответствие экомогических факторов местности биомогическим особенностям сортов и кионов винограда способствует бцагоприятному их приспособцению к новым природно-кииматическим условиям $[8,9,13,16,17]$.

Известно, что сорт винограда наибомее ярко раскрывает свои потенциацьные возможности при применении опредеменных агротехнических приемов, разработанных с учетом его биологических особенностей, а наивысшая экономическая эффективность от возделывания определенного сорта Аостигается при применении промышкенных технологий возделывания винограда индустриального типа $[2,4,5,7,22,24,25]$. Среди агротехнических приемов, применяемых на виноградниках, важное значение отвоАится способам ведения, формирования и обрезки виноградного куста (нагрузка куста глазками, побегами, урожаем, Алина обрезки плодовых моз) $[1,3,6,7,10,18$, 21, 24].

Цемь работы - на основе комплекса агробиологических показателей, хозяйственно ценных признаков оценить перспективность кмонов европейских сортов винограда в зависимости от разработанных эмементов сортовой агротехники в условиях Крыма Аля повышения конкурентноспособности сырья.

Объектом исследований явАямись кмоны сортов винограда: Мускат белый VCR-3, Амеатико 809, Каберне-Совиньон R-5, 2008-2010 гг. посаАки; сорта-этацоны: Мускат белый, Алеатико и КабернеСовиньон, 2006 г. посадки.

\section{Условия проведения исследований.}

Исследования проводились в запаАном районе Южнобережной зоны Крыма (ЮБЗК). Опытные участки расположены на производственных массивах ФГУП «ПАО «Массандра», филиалы: « АиваАия», «Гурзуф», «Таврида». Вариант представлен 45 модельными кустами.

Схема опыта представ ена в табл.1. У кмонов Мускат бемый VCR-3 и Алеатико 802; форма куста - АЗОС-1, схема посаА-
Urdenko N.A., Beibulatov M.R

Tikhomirova N.A..Buival R.A.

VITICULTURE

Таблица 1. Схема разработки технологии возделывания новых сортов и клонов для Крыма в сравнении с эталонными сортами винограда в ЮБЗК

Table 1. Development of the new cultivar and clone cultivation technology scheme in Crimea in comparison with standard grapevine cultivars in the South of Crimea

\begin{tabular}{|c|c|c|c|c|}
\hline Сорт & $\begin{array}{l}\text { Форма } \\
\text { куста }\end{array}$ & $\begin{array}{l}\text { Нагрузка } \\
\text { на куст, гл. }\end{array}$ & $\begin{array}{l}\text { Алина } \\
\text { обрезки } \\
\text { пмоА. } о 03, \\
\text { гц. }\end{array}$ & $\begin{array}{l}\text { Комичество- } \\
\text { во звеньев, } \\
\text { шт. }\end{array}$ \\
\hline \multicolumn{5}{|c|}{ технические сорта винограда } \\
\hline \multirow{3}{*}{ Амеатико 802} & I & 15 & \multirow{3}{*}{3} & 5 \\
\hline & A3OC-1 & 18 & & 6 \\
\hline & Контроль & 12 & & 4 \\
\hline Асеатико & Сорт-эталон (K) О/K & 36 & 6 & 4 \\
\hline \multirow{5}{*}{$\begin{array}{l}\text { Мускат бемый } \\
\text { VCR-3 }\end{array}$} & I & 33 & 8 & 3 \\
\hline & Контромь & 18 & 6 & 2 \\
\hline & I & 23 & & $5+\ll 3 а м о к »$ \\
\hline & A3OC-1 & 26 & 3 & $6+\langle 3 а м о к »$ \\
\hline & Контронь & 18 & & 6 \\
\hline \multirow[t]{2}{*}{ Мускат белый } & Сорт-эталон $(\mathrm{K}) \mathrm{O} / \mathrm{K}$ & 44 & 8 & 4 \\
\hline & I & 24 & 3 & \multirow{2}{*}{4} \\
\hline \multirow{3}{*}{$\begin{array}{l}\text { Каберне- } \\
\text { Совиньон R-5 }\end{array}$} & \multirow{3}{*}{$A / K$} & 36 & 6 & \\
\hline & & 36 & 3 & \multirow{2}{*}{$\cdots 6$} \\
\hline & & 54 & 6 & \\
\hline $\begin{array}{l}\text { Каберне- } \\
\text { Совиньон }\end{array}$ & Сорт-эталон $(K) \Delta / K$ & 54 & 6 & 6 \\
\hline
\end{tabular}

ки кустов 3,0 х 1,25 м и односторонний горизонтальный корАон на среднем штамбе (О/К), схема посадки кустов 3,0 х 1,5 м. У кмона Каберне- Совиньон R-5 и сортов-эталонов - Авусторонний кордон на среднем штамбе $(A / K)$ схема посадки кустов 3,0 х 1,5 м. Почвы на участках - коричневые, бурые горно-лесные, горно-луговые на слабощебнистых тяжелосуглинистых отложениях.

В усмовиях Южнобережной зоны Крыма (ЮБЗК) за 2017 и 2018 гг. среднегодовая температура воздуха составила $+14,1^{\circ} \mathrm{C}$; $14,9^{\circ} \mathrm{C}$, (среднемноголетнее значение $13,5^{\circ} \mathrm{C}$ ), п. Никита. Сумма активных температур $\left(\geq+10^{\circ} \mathrm{C}\right)$ составляет $4072,5^{\circ} \mathrm{C} ; 4429,0^{\circ} \mathrm{C}$ (среднемноголетнее значение $3751,0^{\circ} \mathrm{C}$ ). Осадков выпало 533,1 и 784,0 мм (среднемноголетнее значение 619,6 мм) [15]. Таким образом, наблюдается повышение в среднем за 2017-2018 гг. суммы активных температур на $499,8^{\circ} \mathrm{C}$, в среАнем за Ава года, что поАтвержАает факт высокой тепло-, вмагообеспеченности Южнобережной зоны Крыма.

Исследования проводились по общепринятым в виноградарстве методикам и методическим разработкам [11].

\section{Результаты исследований}

В условиях ЮБК изучаемые кмоны сортов (табл. 2) по показателю «процент плодоносных побегов», при увеличении нагрузки на куст и применении кордонной формы куста A3OC-1, превышали показатели сортов-эталонов (К), а также увеличение нагрузки в 1,5 раза привело к снижению Аанного показателя в разрезе кмонов сортов.

Проведенные исследования показали, что изучаемые сорта в условиях ЮБЗК, при возАелывании изучаемых кАонов сортов по разработанной сортовой агротехнике, формируют очень высокую эмбрионацьную плодоносность: кмон сорта Каберне-Совиньон R-5, кАон сорта А^еатико 802 с вариантами I и «К», кАон сорта Мускат белый VCR-3 на кордонной форме куста A3OC-1 по сравнению с формой куста - (O/К), превышая значения сортовэталонов (К), имели более высокую плодоносность куста (кцон сорта Мускат белый VCR-3 на одностороннем кордоне с нагрузкой на куст 33 глазка. 
Среди вариантов по испытанию разработанной сортовой агротехники у кмонов сортов: Алеатико 802, Каберне-Совиньон R-5, Мускат белый VCR-3 можно выделить смеАующие варианты опыта с оптимацьными агробиологическими показателями: на кмоне сорта Каберне-Совиньон R-5 - II, III варианты опыта с нагрузкой на куст 36 глазков (6 звеньев) с Алиной обрезки плодовых моз на 3 и 6 глазков; на кцоне сорта Амеатико 802 - варианты I и II, где на рукаве куста расположены 6 рожков, на кажАом из которых по 3 глазка, с нагрузкой на куст 18 и 15 глазков; на кмоне сорта Мускат белый VCR-3 агробиологические показатели выше на кустах, сформированных по типу спирацьного кордона - АЗОС-1 и одностороннего горизонтацьного кордона, контрольный вариант с нагрузкой 18 глазков.

В табл. 3 приведены результаты оценки количественных и качественных характеристик изучаемых клонов сортов. Высокие значения коэффициента плодоношения $\left(\mathrm{K}_{1}\right)$ и большая среАняя масса грозАи у кмонов (Алеатико 802, Мускат белый VCR-3, Каберне-Совиньон R-5) в разрезе разработанных нагрузок на куст и Алины обрезки пцодовых $\Lambda 0 з$ обуславливают более высокие значения продуктивности побега (ПП) и урожайности по сравнению с контрольными сортами-эталонами.

У кмона сорта Алеатико 802 с повышением нагрузки на куст увеличивалось количество гроздей, при этом их средняя масса уменьшалась, слеАовательно, и продуктивность побега (ПП) уменьшамась. В разрезе вариантов опыта ПП варьироваца от 201,5 г - при нагрузке - 18 гл. и Ао 315,2 г - при нагрузке 12 гл. У вариантов опыта, где нагрузка на куст была в пределах 15-18 гл. (4-6 рожков) разница по урожайности с контрольным вариантом, гАе нагрузка на куст была минимацьной - 12 гл. (5 рожков) при форме куста А3ОС-1 в варианте I увеличилась на $16,0 \%$, а в варианте II - уменьшикась на $11,0 \%$, разница существенна на $5 \%$-ном уровне значимости, $\left(\mathrm{HCP}_{05}=2,1\right)$, при этом качественные показатели в разрезе вариантов опыта не уступаци контрольному варианту, разница межАу вариантами опыта несущественна, $\mathrm{HCP}_{05}=0,82$, при $\mathrm{F}_{\phi}>\mathrm{F}_{05}$.
Таблица 2. Агробиологические показатели клонов европейских сортов в зависимости от разработанных элементов технологии их возделывания Table 2. Agrobiological characteristics of clones of European cultivars depending on the developed cultivation technology elements

\begin{tabular}{|c|c|c|c|c|c|c|c|}
\hline \multirow[b]{2}{*}{ Вариант } & \multirow[b]{2}{*}{$\begin{array}{l}\text { Нагруз- } \\
\text { ка куста, } \\
\text { гм. }\end{array}$} & \multirow{2}{*}{$\begin{array}{l}\text { Алина } \\
\text { обрезки } \\
\text { плодо- } \\
\text { вых моз, } \\
\text { гц. }\end{array}$} & \multirow[b]{2}{*}{$\begin{array}{l}\text { Раз- } \\
\text { вицось } \\
\text { побегов, } \\
\%\end{array}$} & \multirow[b]{2}{*}{$\begin{array}{l}\text { Пцодо- } \\
\text { носные } \\
\text { побеги, } \\
\%\end{array}$} & \multicolumn{2}{|c|}{ Коэффициент } & \multirow[b]{2}{*}{$\begin{array}{l}\text { Категории } \\
\text { по пмодо- } \\
\text { носности } \\
\text { побега }\end{array}$} \\
\hline & & & & & $\begin{array}{l}\text { плодо- } \\
\text { ноше- } \\
\text { ния }\left(\mathrm{K}_{1}\right)\end{array}$ & $\begin{array}{l}\text { Плодо- } \\
\text { носно- } \\
\text { сти } \\
\left(\mathrm{K}_{2}\right)\end{array}$ & \\
\hline \multicolumn{8}{|c|}{ кмон сорта Анеатико 802} \\
\hline I & 18 & 3 & 86,1 & 75,5 & 1,19 & 1,57 & оч. высокая \\
\hline II & 15 & 3 & 78,7 & 71,2 & 1,09 & 1,54 & высокая \\
\hline Контроль & 12 & 3 & 84,2 & 85,1 & 1,34 & 1,57 & оч. высокая \\
\hline Сорт-этацон $(\mathrm{K})$ & 36 & 6 & 97,2 & 68,6 & 0,96 & 1,40 & высокая \\
\hline $\mathrm{HCP}_{05}$ & - & - & - & - & 0,22 & 0,10 & - \\
\hline \multicolumn{8}{|c|}{ кмон сорта Мускат бемый VCR-3 } \\
\hline $\mathrm{I}(\mathrm{O} / \mathrm{K})^{1}$ & 33 & 8 & 88,5 & 79,1 & 1,03 & 1,20 & высокая \\
\hline Контромь $(\mathrm{O} / \mathrm{K})$ & 18 & 6 & 93,3 & 86,0 & 1,18 & 1,38 & \multirow{4}{*}{ оч. высокая } \\
\hline $\mathrm{I}(\mathrm{A} 3 \mathrm{OC}-1)$ & 23 & 3 & 83,5 & 88,5 & 1,16 & 1,31 & \\
\hline II $(\mathrm{A} 3 \mathrm{OC}-1)$ & 26 & 3 & 84,6 & 80,6 & 1,11 & 1,33 & \\
\hline $\begin{array}{l}\text { Контромь } \\
(\text { АЗОС-1) }\end{array}$ & 18 & 3 & 86,7 & 90,4 & 1,31 & 1,45 & \\
\hline Сорт-этамон $(\mathrm{K})$ & 44 & 8 & 90,7 & 76,4 & 1,00 & 1,17 & высокая \\
\hline $\mathrm{HCP}_{05}$ & - & - & - & - & 0,15 & 0,20 & - \\
\hline \multicolumn{8}{|c|}{ кион сорта Каберне-Совиньон R-5 } \\
\hline I & 24 & 3 & 79,6 & 76,8 & 1,23 & 1,60 & \multirow{4}{*}{ оч. высокая } \\
\hline II & 36 & 6 & 79,2 & 75,4 & 1,23 & 1,63 & \\
\hline III & 36 & 3 & 69,2 & 76,3 & 1,13 & 1,48 & \\
\hline Контромь & 54 & 6 & 79,1 & 77,3 & 1,31 & 1,66 & \\
\hline Сорт-этацон $(\mathrm{K})$ & 54 & 6 & 78,5 & 72,6 & 1,10 & 1,52 & высокая \\
\hline $\mathrm{HCP}_{05}$ & - & - & - & - & 0,16 & 0,12 & - \\
\hline
\end{tabular}

Таблица 3. Урожай и качество винограда изучаемых клонов и сортов винограда в зависимости от элементов агротехники

Table 3. The yield and quality of grapes of the studied clones and grapevine cultivars depending on the agricultural technology elements

\begin{tabular}{|c|c|c|c|c|c|c|c|}
\hline \multirow[b]{2}{*}{ Вариант } & \multirow{2}{*}{$\begin{array}{l}\text { Нагруз- } \\
\text { ка куста, } \\
\text { гц. }\end{array}$} & \multirow{2}{*}{$\begin{array}{l}\text { Алина } \\
\text { обрезки } \\
\text { l пмодо- } \\
\text { вых Аоз, } \\
\text { гА. }\end{array}$} & \multirow[b]{2}{*}{ ПП, г } & \multirow{2}{*}{$\begin{array}{l}\text { Урожай } \\
\text { ность, } \\
\text { т/га }\end{array}$} & \multirow{2}{*}{$\begin{array}{l}\text { Уровень } \\
\text { сахари- } \\
\text { стости } \\
{[14]}\end{array}$} & \multicolumn{2}{|c|}{$\begin{array}{l}\text { Массовая } \\
\text { концентрация }\end{array}$} \\
\hline & & & & & & $\begin{array}{l}\text { сахаров, } \\
\mathrm{r} / 100 \mathrm{~cm}^{3}\end{array}$ & $\begin{array}{l}\text { титруемых } \\
\text { кисмот, } \\
\text { г/Ам }{ }^{3}\end{array}$ \\
\hline \multicolumn{8}{|c|}{ кмон сорта Амеатико 802} \\
\hline I & 18 & 3 & 201,5 & 9,4 & & 25,2 & 5,8 \\
\hline II & 15 & 3 & 225,7 & 7,2 & оч. высо- & 25,7 & 5,7 \\
\hline Контромь & 12 & 3 & 315,2 & 8,1 & кая & 26,0 & 5,7 \\
\hline Сорт-эталон (К) & 36 & 6 & 142,0 & 10,7 & & 25,5 & 5,6 \\
\hline $\mathrm{HCP}_{05}$ & 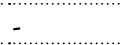 & 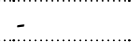 & 100,4 & 2,1 & - & 0,82 & 0,21 \\
\hline \multicolumn{8}{|c|}{ кмон сорта Мускат белый VCR-3 } \\
\hline $\mathrm{I}(\mathrm{O} / \mathrm{K})$ & 33 & 8 & 268,7 & 14,9 & \multirow{5}{*}{ g } & 24,9 & 5,6 \\
\hline Контроль $(\mathrm{O} / \mathrm{K})$ & 18 & 6 & 373,4 & 10,2 & & 25,2 & 5,0 \\
\hline $\mathrm{I}(\mathrm{A} 3 \mathrm{OC}-1)$ & 23 & 3 & 292,1 & 13,8 & & 23,2 & 6,2 \\
\hline II $(\mathrm{A} 3 \mathrm{OC}-1)$ & 26 & 3 & 265,6 & 14,9 & & 23,0 & 6,4 \\
\hline $\begin{array}{l}\text { Контроль } \\
\text { (АЗОС-1) }\end{array}$ & 18 & 3 & 362,2 & 10,9 & & 24,6 & 5,8 \\
\hline $\begin{array}{l}\text { Сорт-эталон (K), } \\
\mathrm{O} / \mathrm{K}\end{array}$ & 44 & 8 & 166,0 & 12,9 & $\begin{array}{l}\text { оч. высо- } \\
\text { кая }\end{array}$ & 25,2 & 5,2 \\
\hline $\mathrm{HCP}_{05} \ldots$ & - & 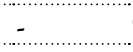 & 98,4 & 2,3 & 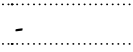 & 1,59 & 0,53 \\
\hline \multicolumn{8}{|c|}{ клон сорта Каберне-Совиньон R-5 } \\
\hline I & 24 & 3 & 360,2 & 12,2 & & 23,1 & 6,1 \\
\hline II & 36 & 6 & 259,9 & 14,8 & & 22,3 & 6,3 \\
\hline III & 36 & 3 & 265,2 & 12,7 & & 21,0 & 6,5 \\
\hline Контроль & 54 & 6 & 221,2 & 10,5 & & 20,8 & 6,5 \\
\hline Сорт-эталон (К) & 54 & 6 & 109,3 & 7,6 & & 20,1 & 6,8 \\
\hline $\mathrm{HCP}_{05}$ & & - & 36,5 & 2,5 & & 0,81 & 0,28 \\
\hline
\end{tabular}

Примечание: изреженность виноградников кмонов сортов до 20\%. 
В опытных вариантах у кмона сорта Мускат бемый VCR-3 как при форме куста оАносторонний горизонтальный кордон, так и АЗОС-1 при увеличенной нагрузке кустов 33 и 26 глазков на куст увеличился показатель ПП, при этом их масса существенно уменьшимась по сравнению с контрольным вариантом опыта на 28,0 и $26,7 \%$. С увеличением количества гроздей повысился урожай с куста на 46,1 и $36,7 \%$. При форме куста A3OC-1 разница в урожае межАу вариантами II и III была несущественна, $\mathrm{HCP}_{05}=2,3$. Варианты опыта при форме куста оАносторонний горизонтацьный корАон и АЗОС-1, гАе кусты нагрузили по 33, 23 и 26 глазков превышали значения урожайности контромьного сорта-эталона на 15,$5 ; 7,0$ и $15,5 \%$ соответственно. Снижение нагрузки кустов глазками улучшимо качество урожая. На качественные показатели кмона сорта Мускат белый VCR-3 оказала применяемая форма куста. При форме куста односторонний горизонтальный кордон массовая концентрация сахаров в соке ягод была выше на 1,45 единицы в среднем по варианту опыта, чем при форме куста A3OC-1. Максимальная концентрация сахаров в соке ягод в разрезе всех вариантов опыта у кмона сорта Мускат белый VCR-3 была при форме куста односторонний горизонтацьный корАон у контрольного варианта опыта и на одном уровне со значениями контроцьного варианта сорта-этацона - 25,2 г/100 $\mathrm{cm}^{3}$.

На кмоне сорта Каберне-Совиньон R-5 изменение нагрузки кустов глазками, Алины обрезки плодовых моз и количества плодовых звеньев существенно повлияло на величину и качество урожая следующим образом. Увеличение нагрузки на куст от 24 Ао 54 глазков в контрольном варианте опыта и увеличении количества звеньев на куст от 4 Ао 6 штук привело к снижению ПП от 14,9 до $38,6 \%$, разница существенна - $\mathrm{HCP}_{05}=36,5$, и урожайности от 16,2 Ао $41 \%$ разница существенна, $\mathrm{HCP}_{05}=2,5$, соответственно от 1,7 Ао 4,3 т/га. Максимацьная концентрация сахаров с оптимальным сочетанием титруемых кислот в соке ягоА винограда соответствует варианту с минимацьной нагрузкой на куст и короткой обрезкой плодовых $\Lambda 03-\mathrm{I}$ вариант, со значениями 23,1 г/100 cм ${ }^{3}$ и 6,1 г/ $\mathrm{Am}^{3}$ по сравнению с контрольным вариантом, гАе применими нагрузку 54 гл. на куст (6 звеньев) - 20,8 г/100 см и 6,5 г/АMㄹ, разница существенна, $\mathrm{HCP}_{05}=8,1$. Оптимацьные сочетания урожайности и качества сырья обеспечивают разработанные варианты II и III, гАе нагрузка на куст - 36 глазков при короткой и среАней Алинах

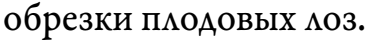

У кмона сорта винограда Алеатико 802 в условиях Западного района Южнобережной зоны Крыма, разработанные элементы сортовой агротехники (табл. 4): форма АЗОС-1, нагрузка 15 глазков на куст при

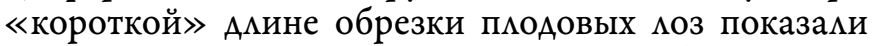
наибольшую перспективность, Ка=0,90 (очень перспективный), хотя Аальнейшее увемичение нагрузки Ао 18 глазков на куст не ухудшимо продуктивность и качество клона сорта Алеатико 802, Ка=0,80 (перспективный).

На кмоне сорта винограда Мускат бемый VCR-3 в результате применения разработанных экементов со- ртовой агротехники установлено, что возделывание Аанного кмона оценивается как очень перспективное при форме куста оАносторонний горизонтальный кордон и минимацьных нагрузках на куст. ОАнако увеличение нагрузки на куст до 33 глазков и применение формы куста АЗОС-1 при нагрузке 23 и 26 глазков обеспечивает перспективное возделывание данного клона по разработанным элементам сортовой агротехники.

Перспективность применения разработанных элементов сортовой агротехники Аця кмона сорта винограда Каберне-Совиньон R-5 при форме куста Авусторонний горизонтальный кордон оценены как перспективные (Ка=0,74-0,77) и превосходят по перспективности контроцьный сорт-эталон, Ка=0,69 (Аостаточно перспективный).

Выводы. Устойчивое производство качественной продукции виноградарства обосновано системной разработкой элементов сортовой агротехники и комплексной оценкой агробиологических и хозяйственных показателей кмонов сортов в сравнении с сортами-эталонами в условиях ЮБК, позволяющих нормаАизовать их и с помощью агротехнических приемов корректировать решения по проблемам укучшения качества продукции.

1. По результатам испытания разработанных экементов сортовой агротехники в условиях ЮБЗК выАелены варианты опыта с оптимальными агробиологическими показателями: на клоне сорта Каберне-Совиньон R-5 - нагрузка - 36 глазков (6 звеньев, Алина обрезки 3 и 6 глазков); на кмоне сорта Ацеатико 802 -нагрузка - 18 и 15 глазков; на кмоне сорта Мускат бе$\Lambda$ Ый VCR-3 форма куста оАносторонний горизонтаАьный корАон, вариант - контромь, и при форме куста А3ОС-1 с нагрузкой 18 глазков.

2. Разработанные элементы технологии у кмонов сортов Алеатико 802, Мускат белый VCR-3, КабернеСовиньон R-5 в ЮБЗК обуславливают более высокие значения урожайности по сравнению с контрольными сортами-эталонами.

3. Рекомендуемые эмементы сортовой агротехники обеспечивают высокие значения ИПП амя исслеАуемых кАонов сортов винограАа в условиях ЮБЗК: от 0,77 (перспективный) - кмон сорта Каберне-Совиньон R-5 до 0,90 (очень перспективный) - кмон сорта Амеатико 802.

\section{Источники финансирования}

Работа выполняется в рамках Государственного задания Минобрнауки Российской Федерации (№ 08332015-0013 и 0833-2019-0021).

\section{Finansing source}

The study is carried out under public assignment of the Minstry of Science and Higher Education of the Russian Federation (№ 0833-2015-0013 и 0833-20190021).

\section{Конфликт интересов}

Не заявлен.

\section{Conflict of interests}

Not declared.

\section{Благодарность}


Авторы выражают благодарность: главному агроному ФГУП «ПАО «Массандра» Поляковой Т.Н., агрономам филиала «Аивадия» ФГУП «ПАО «Массандра» Назаренко И.И., филиала «Таврида» ФГУП «ПАО «МассанАра» Соломенник С.Н., филиала «Гурзуф» Мельник М.Ю. - сбор материала.

Участие авторов: УрАенко Н.А. - анализ полученных данных, написание текста, Бейбулатов М.Р. - концепция исследования, Тихомирова Н.А. и Буйвац Р.А. - сбор и обработка материалов.

\section{Список литературы/References}

1. Бейбулатов М.Р., Урденко Н.А., Тихомирова Н.А., Буйвал Р.А. Оценка агробиологических и хозяйственных признаков клона сорта Мускат белый VCR-3 в условиях Южного берега Крыма // Плодоводство и виноградарство Юга России. - Краснодар, 2018, №51 (03). - С. 88-97.

[Beibulatov M.R., Urdenko N.A., Tikhomirova N.A., Buival R.A. Otsenka agrobiologicheskih i hozyaystvennyh priznakov klona sorta 'Muskat beliy VCR-3'v usloviyah Yuzhnogo berega Kryma [Assessment of the agro-biological and economic characteristics of VCR-3 clone of 'Muscat Beliy' cultivar in the South of Crimea]. Fruit growing and viticulture of the South of Russia. Krasnodar, 2018, №51 (03). pp. 88-97. (in Russian)]

2. Бейбулатов М.Р. Урденко Н.А., Тихомирова Н.А., Буйвал Р.А. Продуктивность европейских клонов сортов в зависимости от сортовой агротехники в условиях Южнобережной зоны Крыма // «Магарач». Виноградарство и виноделие. - Ялта, 2018, №1. - С. 15-18.

[Beibulatov M.R., Urdenko N.A., Tikhomirova N.A., Buival R.A. Produktivnost' yevropeyskih klonov sortov $v$ zavisimosti ot sortovoy agrotekhniki $v$ usloviyah Yuzhnoberezhnoy zony Kryma [The relationship between productivity of European clones of varieties and varietal agrotechnology in conditions of the South Coast of Crimea]. Magarach. Vinogradarstvo $i$ vinodelie $=$ Magarach. Viticulture and Winemaking. - Yalta, 2018. №1. - pp. 15-18. (in Russian)]

3. Бондаренко С.Г. История обрезки и влияние ее на урожай. - Омнибус. - 2002. - №3. - С.15-16.

[Bondarenko S.G. Istoriya obrezki i vliyanie ee na urozhay [The history of trimming and its impact on the yield]. - Omnibus. 2002. - №3. - pp.15-16. (in Russian)]

4. Гусейнов Ш.Н., Чигрик Б.В., Гордеев Н.Г. Реакция интродуцированных сортов винограда Кристалл и Августин на способы ведения и формирования виноградных кустов // Стратегия устойчивого развития и инновационные технологии в садоводстве и виноградарстве: Материалы международной научно-практической конференции, посвященной 80-летию Героя Социалистического Труда, д. с.-х. н., академика Н.А. Алиева. - Махачкала, 2010. - С. 56-61.

[Huseynov Sh.N., Chigrik B.V., Gordeev N.D. Reaktsiya introdutsirovannyh sortov vinograda 'Kristall' $i$ 'Avgustin' na sposoby vedeniya $i$ formirovaniya vinogradnyh kustov [Response of introduced vine cultivars 'Kristall' and 'Aavgustin' on bush training and shaping. Strategiya ustoychivogo razvitiya $i$ innovatsionnye tekhnologii v sadovodstve $i$ vinogradarstve: Materialy mezhdunarodnoy nauchno-prakticheskoy konferentsii, posvyashchennoy 80-letiyu Geroya Sotsialisticheskogo Truda, d. s.-h. n., akademika N.A. Alieva. - Makhachkala, 2010. - pp. 56-61. (in Russian)]

5. Гусейнов Ш.Н., Чигрик Б.В., Нагиев 3.С. Продуктивность интенсивных виноградников на Тамани // Материалы научно-практической конференции. - Новочеркасск. - 2006. - C.86-89.

[Huseynov Sh.N., Chigrik B.V., Nagiyev Z.S. Produktivnost'
УрАенко Н.А., Бейбулатов М.Р.,

Тихомирова Н.А., Буйвал Р.А. intensivnyh vinogradnikov na Tamani [Fertility of intensive vineyards in Taman]. Materialy nauchno-prakticheskoy konferentsii. [Science-to-practice conference proceedings] Novocherkassk. - 2006. - pp. 86-89. (in Russian)]

6. Дикань А.П. Результативное виноградарство. - Симферополь: Бизнес-Информ, 2016. - 276 с.

[Dikan A.P. Rezul'tativnoe vinogradarstvo [Effective viticulture]. - Simferopol: Business-Inform, 2016. - 276 p. (in Russian)]

7. Захарова Е.И. Состояние и основные направления исследований по сортовой агротехнике // Труды ВНИИВиВ им. Я.И. Потапенко. Новочеркасск. - 1975. - Т.11(19). - C.6-21.

[Zakharova E.I. Sostoyanie i osnovnye napravleniya issledovaniy po sortovoy agrotekhnike [The current state and main trends of research in varietal agricultural practices]/// Trudy VNIIViV im. Ya.I. Potapenko. Novocherkassk. - 1975. V.11(19). - pp.6-21. (in Russian)]

8. Казанцева Л.П. Особенности обрезки кустов сорта Мускат белый // Виноделие и виноградарство СССР. 1971. №4. - C.30-32.

[Kazantseva L.P. Osobennosti obrezki kustov sorta 'Muskat belyy' [Peculiarities of bush pruning of 'Muskat Beliy' cultivar. Winemaking and viticulture of the USSR. 1971. - №4. - pp.30-32. (in Russian)]

9. Кухарский М.С. Оптимизация технологических процессов возделывания винограда в Республике Молдова // Дисс. докт. с.-х. н. в форме научного доклада. Кишинев. - 1992. -60 c.

[Kukharsky M.S. Optimizatsiya tekhnologicheskih protsessov vozdelyvaniya vinograda $v$ Respublike Moldova [Process optimization in the viticulture of the Republic of Moldova] // PhD. Diss. Kishinev. - 1992. - 60 p. (in Russian)]

10. Матузок Н.В., Плахотников Н.Н., Трошин Л.П. Оптимизация длины обрезки и нагрузки кустов глазками различных сортов винограда на Тамани // Политематический сетевой электронный научный журнал КубГАУ). - Краснодар: КубГАУ, 2016. - № 10(124). - С. 1162-1181. - IDA [article ID]: 1241610074. - Режим доступа: http://ej.kubagro. $\mathrm{ru} / 2016 / 10 / 74 . p d f$

11. Методические рекомендации по агротехническим исследованиям в виноградарстве Украины / [Под ред. А.М. Авидзба]. - Ялта: ИВиВ «Магарач», 2004. - 264 с.

[Metodicheskie rekomendatsii po agrotekhnicheskim issledovaniyam $v$ vinogradarstve Ukrainy [Methodological recommendations on agricultural research in the viticulture of Ukraine]/ [Ed. by A.M. Avidzba]. - Yalta: Institute of Vine and Wine Magarach, 2004. - 264 p. (in Russian)]

12. Носульчак В.А., Смурыгин А.С., Трошин Л.П. Интродукция генофонда винограда и проблемы его сохранения // Мобилизация и сохранение генетических ресурсов винограда, совершенствование методов селекционного процесса. Новочеркасск, 2008. - С. 55-61.

[Nosulchak B.A., Smurygin A.S., Troshin L.P. Introduktsiya genofonda vinograda i problemy ego sohraneniya [Grapevine gene-pool introduction and preservation concerns]. Nosulchak B.A. Mobilizatsiya i sohranenie geneticheskih resursov vinograda, sovershenstvovanie metodov selektsionnogo protsessa. Novocherkassk, 2008. - pp. 55-61. (in Russian)]

13. Оганесянц Л.А. Виноградарство и виноделие Российской Федерации. Состояние и прогноз // Виноградарство и виноделие. 2011. - №1. - С. 4-5.

[Oganesyantz L.A. Vinogradarstvo i vinodelie Rossiyskoy Federatsii. Sostoyanie i prognoz [Viticulture and winemaking of the Russian Federation. Current state and estimates.]. Viticulture and winemaking. 2011. - №1. - pp. 4-5. (in Russian)] 
14. Простосердов Н.Н. Изучение винограда для определения его использования. - М.: Пищепромиздат, 1963. - 79 с.

[Prostoserdov N.N. Izuchenie vinograda dlya opredeleniya ego ispol'zovaniya [Study of grapevine to determine its use]. - M.: Food industpublishing, 1963. - 79 p. (in Russian)]

15. Расписание погоды. - Режим доступа: https://rp5.ru/ (дата обращения 1.02.2018-1.11.18).

[Weather forecast. - Access through: https://rp5.ru/ (access date 1.02.2018-1.11.18).]

16. Серпуховитина К.А. Доминирующие факторы эффективного виноградарства и виноделия // Виноделие и виноградарство. - 2005. - № 5. - С. 10-12.

[Serpukhovitina K.A. Dominiruyushchie faktory effektivnogo vinogradarstva $i$ vinodeliya [Dominant factors of effective viticulture and winemaking]. Vinogradarstvo $i$ vinodelie $=$ Viticulture and winemaking. 2005. № 5. pp. 10-12. (in Russian)]

17. Трошин Л.П. Ампелография и селекция винограда. Краснодар: Издательский цех «Вольные мастера», 1999. - 138 c.

[Troshin L.P. Ampelography and selection of grapes. - Krasnodar: Izdatel'skiy tsekh Vol'nye mastera [Publishing House 'Free Masters'], 1999. - 138 p. (in Russian)]

18. Чаусов В.М. Влияние длины плодовых лоз на урожайность и качество винограда сорта Молдова // Научный журнал КубГАУ. - 2016. - №118. - С. 87-112.

[Chausov V.M. Vliyanie dliny plodovyh loz na urozhaynost' $i$ kachestvo vinograda sorta 'Moldova' [The impact of the length of fruiting canes on fertility and quality of 'Moldova' grapes] . Scientific journal of Kuban State Agrarian University. - 2016. - №118. - pp. 87-112. (in Russian)]
19. Якименко Е.Н., Гугучкина Т.К., Панкин М.И. Перспективы производства красных вин высшей категории качества / // Известия ВУЗов. Пищ. технология. 2004. - № 5-6. - C. 30-31.

[Yakimenko E.N., Guguchkina T.K., Pankin M.I. Perspektivy proizvodstva krasnyh vin vysshey kategorii kachestva [Prospects for the production of extra fine red wines]. Izvestiya Vuzov. Pishch. tekhnologiya. [University News. Foodtechnology] 2004. № 5-6. pp. 30-31. (in Russian)]

20. Aigrain P. World Vitivinicultural Outlook. March 1998. Bulletin de l'O.I.V. revue internationale. 1998. Vol. 71-805806. P. 310-323.

21. Calo A. Forme di allevamento e sistemi di potatura della vitae (seminario). Arboree, Universitata di Pisa, 1968. 8. P. 3-50.

22. Carbonneau A. Training system and wine quality: The misleading discussions about the role of vine spacingin 'lyre culture. Rivista di Viticoltura e di Enologia, Conegliano. 1991. V. 44 (4). P. 329-333.

23. Colapietra M., Catalane V. Valutazione agronomica e commerciale di 16 nuve cultivar di uve apurene / M. Colapietra. L'Informatore Agrario. 1988. Vol.44. N27. P.45-59.

24. Cosmo J. et all. Bases scientifiques des systèmes de taille et de conduite haute de la vigne. Bull. O. I. V., 42. 1969, 455. P. 5-17.

25. Guhgare J.B. Studies on pruning of grape. Vitis, 1968, 2. - P. 120-123.

ORCID ID:

Урденко H.A. https://orcid.org/0000-0002-8073-5482

Бейбулатов M.P. https://orcid.org/0000-0003-4138-0823

Тихомирова H.A. https://orcid.org/0000-0002-2486-1257

Буйвал P.A. https://orcid.org/0000-0003-4149-2657 